\title{
The trkA Receptor Mediates Growth Cone Turning toward a Localized Source of Nerve Growth Factor
}

\author{
Gianluca Gallo, ${ }^{1}$ Frances B. Lefcort, ${ }^{2}$ and Paul C. Letourneau ${ }^{1}$ \\ ${ }^{1}$ Department of Cell Biology and Neuroanatomy, University of Minnesota, Minneapolis, Minnesota 55455, and \\ 2Department of Biology, Montana State University, Bozeman, Montana 59717
}

\begin{abstract}
We have developed an in vitro system for studying the interaction of chick dorsal root ganglion neuronal growth cones with a localized source of nerve growth factor (NGF) covalently conjugated to polystyrene beads. Growth cones rapidly turned and migrated under NGF-coated beads in a process that involved the initial formation of persistent contact with a bead, followed by directed flow of cytoplasm toward the point of contact. A role for the local activation of the high-affinity NGF receptor trkA was suggested by a strong inhibition of the turning response by (1) the addition of an antibody against the extracellular portion
\end{abstract}

of trkA, (2) the elevation of the background concentration of NGF to saturate trkA, or (3) the presence of a concentration of the drug K252a that inhibits trkA activation. NGF binding to the pan-neurotrophin receptor p75 is also involved but is not required for turning. These data show a new role for both the trkA and the p75 receptors: the mediation of local events in the guidance of nerve growth cones.

Key words: growth cone; nerve growth factor; trkA; $p 75$; guidance; filopodia
The machinery for nerve fiber guidance and morphogenesis resides in the fiber terminus, called the growth cone (Mitchison and Kirschner, 1988; Letourneau et al., 1991). Growth cones sample their environment using filopodial and lamellar protrusions, and when these structures detect positive or negative guidance cues, growth cones steer toward or away from the cue (Oakley and Tosney, 1993; Gomez and Letourneau, 1994; Fan and Raper, 1995; Kuhn et al., 1995; Goodman, 1996). During such interactions, cytoskeletal rearrangements redirect growth cone migration (Bentley and O'Connor, 1994; Lin et al., 1994; Tanaka and Sabry, 1995; Challacombe et al., 1996).

Neurotrophins have several roles in neuronal development, ranging from regulation of cell survival to stimulation of nerve fiber elongation and sprouting (Farinas and Reichardt, 1996; Henderson, 1996). Nerve growth factor (NGF) was the first identified neurotrophin (Heumann, 1994; Henderson, 1996). In addition to mediating neuronal survival and other retrograde interactions between neurons and their targets, NGF may locally regulate axonal morphogenesis (Hoyle et al., 1993; Campenot, 1994; Kennedy and Tessier-LaVigne, 1995; Berninger and Poo, 1996). In vitro substratum-bound NGF and gradients of soluble NGF can direct elongating dorsal root ganglion (DRG) axons (Letourneau, 1978; Gundersen and Barrett, 1979; Gundersen, 1985). In vivo, sympathetic axons abundantly innervate sites of NGF overexpression or infusion (Menesini-Chen et al., 1978; Hassankhani et al., 1995). Evidence suggests that NGF is not responsible for long-range axonal guidance (Lumsden and Da-

\footnotetext{
Received March 18, 1997; revised May 5, 1997; accepted May 7, 1997.

This research was supported by National Institutes of Health Grants HD19950 (P.C.L.) and NS35714 (F.B.L.), and by a grant from the Minnesota Medical Foundation (P.C.L.). Production of the CTA antibody was supported by the Howard Hughes Medical Institute. We thank Dr. Jean Challacombe for critical reading of this manuscript and Ms. Florence Roche for technical assistance.

Correspondence should be addressed to Dr. Paul C. Letourneau, Department of Cell Biology and Neuroanatomy, 4-144 Jackson Hall, 321 Church Street NE, University of Minnesota, Minneapolis, MN 55455.

Copyright (C) 1997 Society for Neuroscience $0270-6474 / 97 / 175445-10 \$ 05.00 / 0$
}

vies, 1983; Davies et al., 1987). However, roles for NGF in axonal guidance are suggested by the early production of neurotrophins in targets of DRG and sympathetic axons (Ebendal and Persson, 1988; Hallbook et al., 1995), by cells along their trajectories (Mearow et al., 1993; Elkabes et al., 1994), and by the expression of neuronal NGF receptors before axons reach their targets $(\mathrm{Mu}$ et al., 1993; Wyatt and Davies, 1993; Hallbook et al., 1995).

It is unknown which NGF receptors mediate local responses to NGF (Dobrowsky et al., 1994; Kaplan and Stephens, 1994; Barbacid, 1995; Greene and Kaplan, 1995). After binding NGF, the high-affinity trkA receptor $\left(\sim 1 \mathrm{ng} / \mathrm{ml} K_{\mathrm{d}}\right.$ ) (Weskamp and Reichardt, 1991) undergoes dimerization followed by autophosphorylation and a signaling cascade (Barbacid, 1995). The p75 receptor binds NGF with lower affinity $\left(\sim 40 \mathrm{ng} / \mathrm{ml} \quad K_{\mathrm{d}}\right)$ (Weskamp and Reichardt, 1991) and activates a different signaling pathway (Dobrowsky et al., 1994). The p75 receptor may also potentiate the interaction of trkA with NGF (Barker and Shooter, 1994; Huber and Chao, 1995; Wolf et al., 1995). NGF-responsive DRG neurons express up to 20 times more cell surface p75 receptors than trkA receptors (Weskamp and Reichardt, 1991; Meakin and Shooter, 1992). p75 is called the pan-neurotrophin receptor, because it binds several neurotrophins (Barbacid, 1995).

We now present an in vitro system for studying growth cone guidance by a localized source of neurotrophins. We covalently bound NGF to polystyrene beads and studied the response of DRG growth cones to contact with the beads. After contacting an NGF-coated bead, most growth cones turned and migrated toward the bead in a response that requires the local activation of the high-affinity NGF receptor, a novel role for trkA. The data also support a role for the p75 NGF receptor in the turning response.

\section{MATERIALS AND METHODS}

Cell culture. Lumbosacral DRG were dissected from embryonic day 9-11 white Leghorn chicken embryos and dissociated using $0.25 \%$ crude trypsin in $\mathrm{Ca}^{2+} / \mathrm{Mg}^{2+}$-free PBS, $\mathrm{pH} 7.89$, followed by mechanical trituration (Luduena, 1973). Cells were then suspended in F12 serum-free 
medium (Life Technologies, Grand Island, NY) supplemented with 0.4 $\mathrm{mg} / \mathrm{ml}$ sodium pyruvate, $20 \mathrm{~nm}$ progesterone, $5 \mathrm{ng} / \mathrm{ml}$ sodium selenite, 10 $\mathrm{mM}$ phosphocreatine, $5 \mathrm{mg} / \mathrm{ml}$ insulin, $100 \mathrm{mg} / \mathrm{ml}$ transferrin, $5 \mathrm{mg} / \mathrm{ml}$ bovine serum albumin, and $0.05-15 \mathrm{ng} / \mathrm{ml} \beta \mathrm{NGF}$, and buffered with HEPES. (NGF was obtained from R \& D Systems, Minneapolis, MN; all other additives were obtained from Sigma Chemical, St. Louis, MO). Cell suspension $(1 \mathrm{ml})$ was then placed on a heat-sterilized coverslip mounted over a $22 \mathrm{~mm}$ hole drilled into the bottom of a $35 \mathrm{~mm}$ tissue culture dish. Before culturing, glass coverslips were coated with $50 \mu \mathrm{g} / \mathrm{ml}$ fibronectin (Life Technologies) for $16-24 \mathrm{hr}$ at $4^{\circ} \mathrm{C}$. Cultures were incubated in a humidified $\mathrm{CO}_{2}$-free chamber at $40^{\circ} \mathrm{C}$ for $16-24 \mathrm{hr}$.

Reagents. K252a and KT5926 were obtained from Biomol Research Laboratories (Plymouth Meeting, PA). Solutions (200 mM) were prepared in DMSO and stored at $0^{\circ} \mathrm{C}$. Solutions were made fresh on the day of use. NGF was purchased from R \& D Systems and diluted to the final concentration required by individual experiments from a $5 \mathrm{mg} / \mathrm{ml}$ stock solution, kept at $-20^{\circ} \mathrm{C}$, on the day of use. Brain-derived neurotrophic factor was a gift of Dr. E. Brewster (Regeneron, NY) and stocked as a 5 $\mathrm{mg} / \mathrm{ml}$ solution at $2^{\circ} \mathrm{C}$. Polyclonal anti-L1 was generously provided by Dr. Vance Lemmon, Case-Western Reserve University (Letourneau and Shattuck, 1989).

Preparation of NGF-coated beads. The carbodiimide method (Polysciences, Warrington, PA) was used to covalently couple proteins (NGF and cytochrome-C) to $10-\mu \mathrm{m}$-diameter polystyrene carboxylated beads. Cytochrome-C type VI was from Sigma, and beads and buffers were obtained from Polysciences. The protein-bead coupling procedure was performed at room temperature. Carboxylated beads $(2.5 \% ; 0.5 \mathrm{ml}$; containing $\sim 2.27 \times 10^{7}$ beads) was washed twice with $1.5 \mathrm{ml}$ of carbonate buffer, after which beads were washed twice with $1.5 \mathrm{ml}$ phosphate buffer. For these and subsequent steps, washing refers to centrif uging the bead suspension for $5 \mathrm{~min}$ in a microcentrifuge (Costar, model 10) followed by the removal of the supernatant and resuspension of the bead pellet. Freshly prepared $2 \%$ carbodiimide $(0.625 \mathrm{ml})$ (Sigma) phosphate buffer solution was then used to resuspend the beads, followed by mixing for $4 \mathrm{hr}$ using a rotary shaker. The beads were then washed with $1 \mathrm{ml}$ borate buffer three times and finally suspended in $1 \mathrm{ml}$ of borate buffer containing $50 \mu \mathrm{g}$ of NGF and allowed to mix on a rotary shaker overnight. The next day, $50 \mathrm{ml}$ of $0.25 \mathrm{M}$ ethanolamine (Sigma) in borate buffer was added to the bead suspension and mixed for $30 \mathrm{~min}$ at room temperature. Beads were then pelleted, and the supernatant was stored at $0^{\circ} \mathrm{C}$ for determination of the amount of NGF that had not bound to the beads. Beads were then washed in $1 \mathrm{ml}$ of borate buffer containing $10 \mathrm{mg}$ of bovine serum albumin, and the suspension was mixed for $30 \mathrm{~min}$ on a rotary shaker. This step was then repeated. For storage purposes, the beads were washed and suspended in $0.5 \mathrm{ml}$ of storage buffer and stored at $2^{\circ}-4^{\circ} \mathrm{C}$.

Videomicroscopy. Cultures were placed on an inverted microscope (IM-35, Carl Zeiss, Thornwood, NY) under an air curtain incubator (ASI 400, Carl Zeiss) that maintained the temperature of the medium at a constant $40^{\circ} \mathrm{C}$. Growth cones were visualized with phase-contrast optics, and images were sent to a computer using a Newvicon video camera (NC-65, Dage-MTI, Michigan City, IN). Image enhancement and morphometric measurements were performed using IMAGE 1 software (Universal Imaging, West Chester, PA) running on a $486 / 33 \mathrm{MHz}$ computer (Gateway 2000, North Sioux City, SD). Averaged (16 frames collected over $0.5 \mathrm{sec}$ ) and digitally contrast-enhanced images were obtained every $30 \mathrm{sec}$ and stored on optical disks (TQ-FH331, Panasonic Industrial, Secaucus, NJ) using an optical disk recorder (TQ-3038F, Panasonic Industrial).

Data collection and analysis. Cultures were grown overnight in the desired final concentration of NGF $(0.05-100 \mathrm{ng} / \mathrm{ml})$. Beads were prepared in medium containing the desired final concentration of NGF and added to the culture, resulting in $\sim 4$ beads $/ 100 \mu \mathrm{m}^{2}$. The beads were allowed to settle for $30 \mathrm{~min}$, and the cultures were then inspected for growth cones in the vicinity of one or more beads. After the addition of beads, with or without pharmacological blocking agents or antibodies, each culture was used for a period of up to $3 \mathrm{hr}$. Recording of the interaction between a growth cone and a bead was initiated before initial contact. Observation ended when one of the following criteria was met: (1) the C-domain of the growth cone (distal edge of the phase dark portion of the growth cone) had migrated under the bead and was migrating out from the bead beyond the point of first contact, or (2) the $\mathrm{C}$-domain of the growth cone had not migrated underneath the bead and had extended past the bead. Only growth cones that were not turning at the time of first contact were used for data collection, thereby preventing a source of sampling bias. Once an apparent filopodial or lamellar contact with the bead had occurred, the angle at which the interaction took place $(\alpha)$ was determined by drawing a line connecting the apparent center of the growth cone's C-domain to the point of contact with the bead and measuring the angular displacement of this line from the main nerve fiber axis. The main nerve fiber axis was defined as the line connecting the center of the $\mathrm{C}$-domain with a point in the middle of the nerve fiber shaft $10 \mu \mathrm{m}$ behind the growth cone. The angle at which the growth cone migrated was then determined by noting the center of the $\mathrm{C}$-domain when observation was terminated and drawing a line connecting this point with the point marking the center of the $\mathrm{C}$-domain when the interaction had begun and expressing the angle $(\beta)$ relative to the same axis used to determine $\alpha$. If multiple contacts were made by a growth cone, only the $\alpha$ angle of the first contact was noted. All annotations of growth cone behavior (e.g., nerve fiber axis, angles $\alpha$ and $\beta$ ) during interactions with beads were made on sheets of acetate laid over the monitor's screen. This also allowed us to mark the position of the bead to determine whether the bead had moved during the interaction.

A turn was defined as a movement of the growth cone's C-domain that placed it underneath the bead. A reorientation of the growth cone was defined as a displacement of the $\mathrm{C}$-domain toward the bead that did not result in the placement of the $\mathrm{C}$-domain underneath the bead, which by the end of the observation resulted in the C-domain being located past the bead but not beneath it. Determination of the position of the $\mathrm{C}$-domain during the interaction also allowed us to discriminate whether the growth cone turned by lateral displacements of the growth cone versus the engorgement of growth cone lamellipodia or filopodia by cytoplasmic flow from the C-domain.

Regardless of the type of bead, or the result of the interaction with the bead, in $\sim 50 \%$ of growth cone interactions ( $\mathrm{NGF}=47 \%$; cyto- $\mathrm{C}=$ $46 \%$ ), the beads were picked up and transported onto the growth cone's surface. If a bead was picked up before any growth cone movement occurred, the growth cone was observed until it had migrated at least as far as the distance between its original position at the time of bead pick-up and the position of the bead before pick-up. If growth occurred in the direction of the bead's previous location, then the interaction was considered to have resulted in a turning response by the growth cone (Fig. 1).

Immunocytochemistry. Actin filaments were stained using fluoresceinconjugated phalloidin (Molecular Probes, Eugene, OR). Indirect immunofluorescence was conducted using bivalent polyclonal rabbit primary antibodies to the extracellular domains of trkA, which we called CTA, and p75 (Chex; the gift of Dr. L. Reichardt, University of California at San Francisco), and secondary goat anti-rabbit antibodies conjugated to rhodamine (Jackson Immunoresearch, West Grove, PA). DRG cultures (18- to 24-hr-old) were fixed with $4 \%$ paraformaldehyde containing $0.04 \%$ glutaraldehyde. After a 15 min fixation, the cells were rinsed with calcium and magnesium-free PBS (CMF-PBS), exposed to $1 \mathrm{mg} / \mathrm{ml}$ sodium borohydride (Sigma) for $15 \mathrm{~min}$ and then rinsed in CMF-PBS. In primary experiments, we found that not extracting the cells increased the staining on nerve fibers and growth cones. Phalloidin $(1 \mathrm{U} / 100 \mathrm{ml})$ and the primary antibodies (CTA, $10-100 \mu \mathrm{g} / \mathrm{ml}$; Chex, 7-70 $\mu \mathrm{g} / \mathrm{ml}$ ) were diluted in CMF-PBS containing either a $1 \%$ Carnation nonfat dry milk solution for Chex (MS, Nestle Food Company, Glendale, CA) or 20\% goat serum (GS, ICN, Costa Mesa, CA) for the trkA antibodies and applied to cells for $45 \mathrm{~min}$. After this, the cells were rinsed first in CMF-PBS and then soaked in MS for $15 \mathrm{~min}$. The secondary antibody was applied for a $45 \mathrm{~min}$ period, followed by rinsing with CMF-PBS and a $15 \mathrm{~min}$ incubation in MS/GS. Several dilutions of antibodies were used to determine the concentrations of primary and secondary antibodies that optimized staining. Final rinses in CMF-PBS and distilled deionized water were performed before mounting in media containing 10 $\mathrm{mg} / \mathrm{ml} p$-phenylenediamine (Sigma). Cells were then visualized using a confocal microscope (Bio-Rad MRC1024, Hercules, CA), and images were stored in digital format (Challacombe et al., 1996). Omission of the primary antibodies resulted in no staining.

Characterization of NGF-coated beads. As determined by optical density measurements of the NGF that did not bind to the beads $(n=4,44 \pm 1.4$ $\mu \mathrm{g}$ NGF bound to beads), each bead is expected to have bound $2 \mathrm{pg}$ of NGF. Because the beads have a $10 \mu \mathrm{m}$ diameter and NGF is expected to have bound uniformly on the surfaces of beads, this means that the density of NGF bound at the surface of the bead was $\sim 6 \mathrm{fg} / \mu \mathrm{m}^{2}$. Admittedly, we do not know the orientation(s) at which NGF bound to the surface of the beads. The reaction used to couple the proteins to carboxylated beads is expected to have linked L-, $\mathrm{H}-$, and A terminal groups with the activated $\mathrm{C}$ 

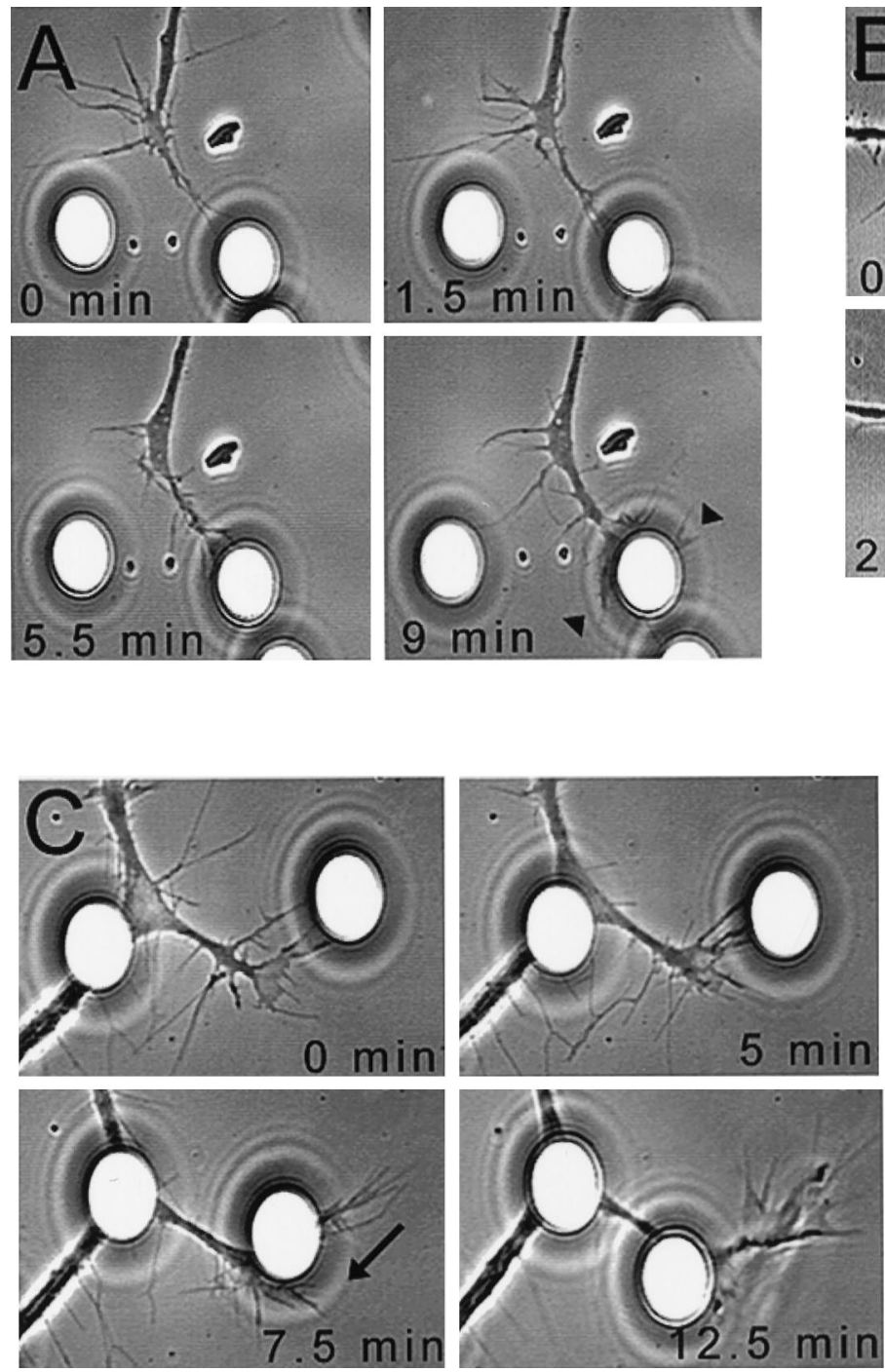
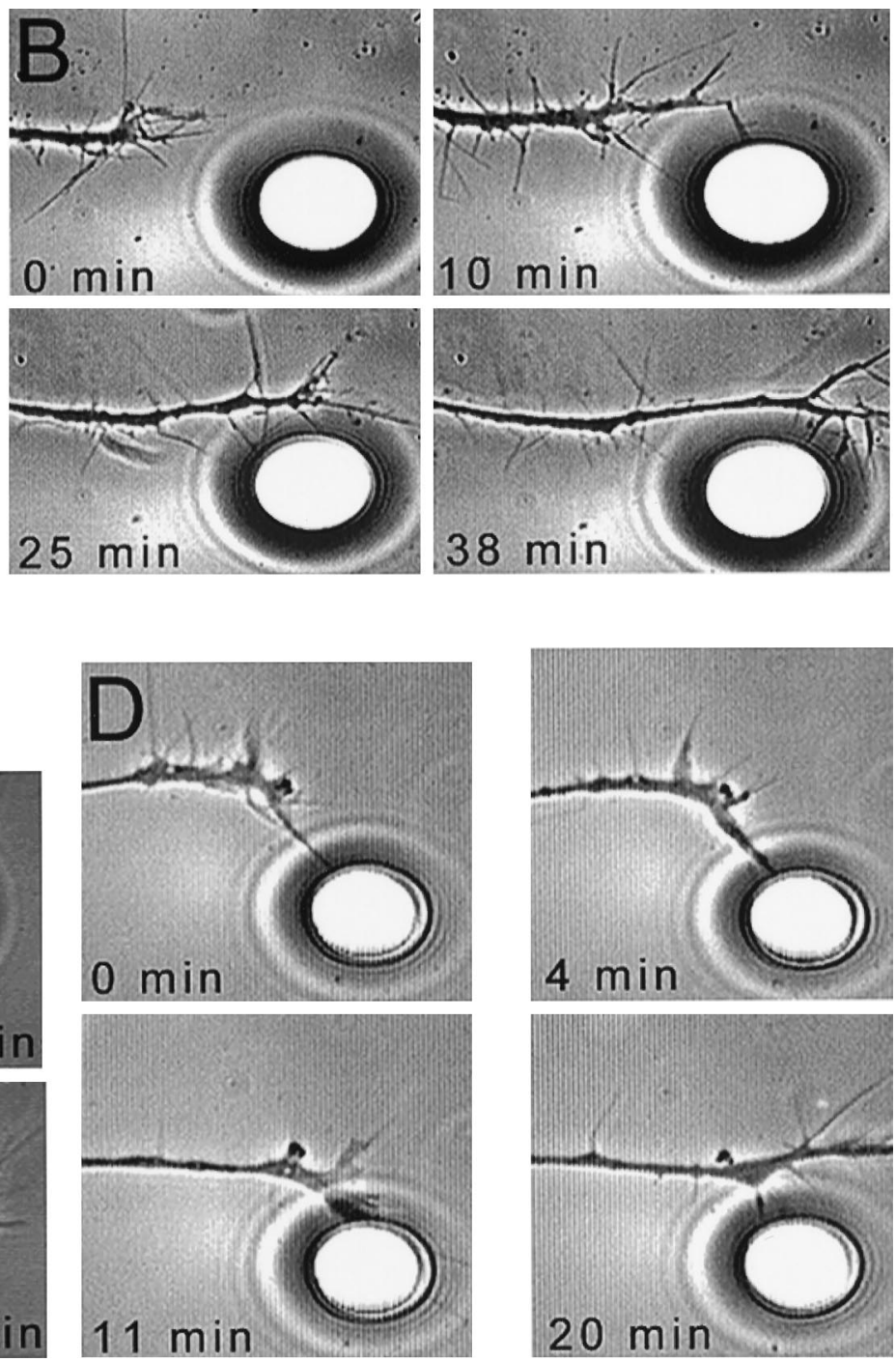

Figure 1. Growth cone behavior during interactions with beads. $A$, Example of growth cone contact with an NGF-coated bead in the presence of 0.05 $\mathrm{ng} / \mathrm{ml}$ background NGF. Initial filopodial contact was established (0 min). The filopodial contact underwent darkening/thickening (1.5 min). Engorgement of the filopodial contact by the growth cone cytoplasm occurred $(5.5 \mathrm{~min})$, and a new growth cone was subsequently formed underneath the bead (9 min, arrowheads point to filopodia extending from underneath the bead). B, Example of growth cone contact with a cyto-C-coated bead. Although filopodial contacts occurred, the growth cones did not turn toward the bead. $C$, Example of NGF-coated bead being picked up by the growth cone, followed by turning toward the initial position of the bead. The growth cone established an initial filopodial contact with the NGF-coated bead (0 min), and subsequently the bead was translocated from its original position onto the nerve fiber (5-7.5 min, arrow indicates the direction in which the bead was displaced). The growth cone then proceeded to migrate in the direction of contact with the bead (12.5 min), even though the bead was no longer present at its original location. $D$, Example of aborted turn in the presence of $500 \mathrm{~nm} \mathrm{KT5926.} \mathrm{The} \mathrm{growth} \mathrm{cone} \mathrm{initially} \mathrm{exhibited} \mathrm{behavior} \mathrm{characteristic}$ of a turning response ( $0-11 \mathrm{~min}$, compare with $A)$. However, the turn was subsequently aborted $(20 \mathrm{~min})$, and the growth cone continued migrating past the bead. Diameter of a bead, $10 \mu \mathrm{m}$.

terminal groups on the surface of the bead. Therefore, the NGF molecule may have adopted several orientations on the beads.

Using neuritogenesis as a bioassay, we have noted that a small amount of NGF appears to detach from the beads during extended time periods ( $\geq 24 \mathrm{hr}$; data not shown). However, because our experiments were performed during the first $3 \mathrm{hr}$ after bead addition to cultures, it is unlikely that microgradients of NGF formed around the beads. In addition, as noted in Results, guidance by NGF-coated beads required filopodial contact, and the contacting filopodium behaved differently from adjacent noncontacting filopodia.

\section{RESULTS}

\section{DRG growth cones turn toward contacts with NGF-coated beads}

With $0.05 \mathrm{ng} / \mathrm{ml} \mathrm{NGF}$ in the culture medium, $77 \%(n=27)$ of DRG growth cones that contacted an NGF-coated bead turned and migrated toward the bead (Fig. 1). This low concentration of background NGF in the culture medium supports survival and neuritogenesis of NGF-dependent neurons without saturating trkA NGF receptors. In contrast, only $18 \%(n=22)$ of growth cones turned toward beads coated with cytochrome-C (cyto-C, a protein with the approximate size and charge of NGF) (Fig. 1). In a separate experiment using a higher NGF background (1.0 vs $0.05 \mathrm{ng} / \mathrm{ml}), 22 \%(n=18)$ of growth cones turned toward cyto-C beads. Hence, $20 \%$ was regarded as the control level of turning toward protein-coated polystyrene beads of this size and density.

During interactions with NGF-coated beads, growth cones exhibited the following characteristic sequence of behaviors: (1) a filopodium contacted the bead, (2) the contact was retained, (3) the contact became darker and thicker, (3b) sometimes the 
growth cone side-stepped (moved laterally) toward the bead, (4) the contact underwent engorgement (movement of cytoplasm into the filopodial or lamellipodial contact with the bead), (5) growth cone structures formed at the distal portion of the engorged contact, and (6) axonal elongation continued in a new direction that was dictated by the angle at which it had first contacted the bead.

Turning began with the formation of a stable contact of a filopodium or lamellipodium with an NGF-coated bead. Because of the curvature of the beads, it was impossible to be absolutely certain that a filopodium was contacting a bead. However, DRG filopodia and lamellipodia are highly dynamic, exhibiting protrusion, retraction, lateral/three-dimensional motion, and buckling. In control conditions on fibronectin substrata, the mean life span of a filopodium is $2.23 \pm 0.18 \mathrm{~min}$ (mean $\pm \mathrm{SEM} ; n=57$ filopodia sampled from 11 growth cones). Similarly, the mean time that filopodia spend at their maximal length is $1.63 \pm 0.15$ min (mean + SEM). Only 18 and $5 \%$ of filopodia have life spans $>4$ or $5 \mathrm{~min}$, respectively. Hence, we defined a persistent contact with a bead as meeting the following two criteria: (1) the filopodium must appear to have contacted a bead, and (2) the apparent contact must be immobile for $>5 \mathrm{~min}$. The life span of filopodia that did not contact beads was not different across experimental and control groups (Dunn's nonparametric ANOVA, $p>0.05$ ).

The manner of growth cone turning was related to the lamellar versus filopodial morphology of the growth cone-bead contact. Eight of nine growth cones that contacted beads with fan-shaped lamellae turned via cytoplasmic engorgement toward the NGFcoated beads. Only one side-stepped toward the bead. On the other hand, growth cones that exhibited either only filopodia or a mixture of filopodia and small transient lamellipodia at the time of contact engaged in combinations of side-stepping and engorgement of contacts to turn toward NGF-coated beads. Of the growth cones that turned toward NGF-coated beads, $48 \%$ of growth cones did so by localized engorgement, $37 \%$ underwent a mixture of side-stepping and engorgement, and $15 \%$ only sidestepped $(n=21)$.

Qualitative observations indicated that turns were directed accurately toward the initial contact with an NGF-coated bead. To quantify the accuracy of growth cone turning, we expressed the accuracy of a turn as the ratio of the angle of initial contact $(\alpha)$ to the angle of the turn ( $\beta$; see Materials and Methods). This ratio is 1 if the angle of turn is the same as the angle of the initial contact, and deviates from 1 if the turn occurred to the left or right of the initial angle of contact. The average value of the ratio of the $\alpha / \beta$ measurements for growth cone turns during interactions with NGF-coated beads was $1.07 \pm 0.09$ (mean \pm SEM), showing that growth cone turning toward NGF-coated beads was quite accurate. The mean angle of initial contact with NGFcoated beads $(\alpha)$ was $40.7 \pm 4.7$ (mean \pm SEM). Turning toward an NGF-coated bead was rapid, because engorgement of contacts with NGF-coated beads occurred $8.71 \pm 1.17$ min (mean \pm SEM; range, 3-18 $\mathrm{min}$ ) after the first persistent contact with a bead.

Three of the four growth cones that turned toward contacts with cyto-C-coated beads did so by engorgement, and one side-stepped ( $n=22 ; 0.05 \mathrm{ng} / \mathrm{ml} \mathrm{NGF}$ background). In three instances, growth cones that contacted cyto-C beads extended small branch-like processes toward the bead, but these were not permanent, and because the growth cones did not turn, these were not scored as turns. Persistent filopodial contacts were observed in only $23 \%$ of interactions when growth cones did not turn after contacting cyto- $\mathrm{C}$ beads, or $38 \%$ of the interactions, if the aforementioned formation of transient branches are included in the analysis.

\section{Immunocytochemical visualization of trkA and p75 receptors on NGF-treated DRG neurons}

We used antibodies raised against the extracellular portions of the trkA (CTA) and p75 (Chex et al., 1991) receptors, to visualize the distribution of both types of NGF receptors on the surfaces of DRG neurons cultured overnight in $0.05 \mathrm{ng} / \mathrm{ml}$ NGF. As determined by Western blotting and immunostaining of non-neuronal cells engineered to express individual species of avian trk receptors, CTA is specific for trkA and does not recognize trkB or trkC (Oakley et al., 1997). Staining of actin filaments with phalloidinFITC was used to visualize filopodia and lamellipodia in relation to the distribution of the trkA and p75 receptors. p75 was expressed everywhere on the surface of DRG neurons grown in $0.05 \mathrm{ng} / \mathrm{ml} \mathrm{NGF}$ (Fig. $2 A, B$ ). At $7 \mu \mathrm{g} / \mathrm{ml} \mathrm{Chex,} \mathrm{which} \mathrm{gave}$ optimal staining while minimizing background, $68 \%(n=125)$ of neurons stained brightly for p75, whereas $32 \%$ clearly exhibited less bright p75 staining. In faintly stained neurons, staining was faint over the entire cell. On well-stained neurons, p75 staining was found on the C-domain, as well as on lamellipodia and nearly all filopodia. Some non-neuronal cells, which by their morphology appeared to be Schwann cells, were also stained by anti-p75 (data not shown).

Almost all neurons $(96 \%, n=47)$ that had extended nerve fibers in the presence of $0.05 \mathrm{ng} / \mathrm{ml} \mathrm{NGF}$ exhibited bright somatic immunofluorescence with $25 \mu \mathrm{g} / \mathrm{ml}$ anti-trkA. TrkA was also localized on nerve fibers as well as on growth cone filopodia, lamellae, and the $\mathrm{C}$-domain (Fig. $2 C, D$ ). Fibroblasts, as judged by the presence of stress fibers, did not stain for trkA (Fig. 2).

\section{Block of the turning response using trkA and p75 antibodies}

The availability of antibodies against the extracellular portions of trkA and p75 receptors provided a means to test the role of these receptors in the turning of DRG growth cones toward NGF-coated beads. The Chex antibody has been shown previously to prevent the binding of NGF to the p75 receptor on avian neurons (Weskamp and Reichardt, 1991). Because the bivalent trkA antibody CTA supports survival of DRG neurons in the absence of $\mathrm{NGF}$, it may be that CTA activates the receptor by dimerizing trkA monomers. Fab fragments of CTA do not support survival of DRG neurons in the absence of NGF, and nor do they block the neurotrophic effects of NGF on DRG neurons (data not shown).

The anti-trkA antibody CTA was added to cultures concurrently with NGF-coated beads, resulting in a final IgG concentration of $25 \mu \mathrm{g} / \mathrm{ml}$, and experiments were initiated 30 min later. In the presence of anti-trkA, growth cones did not turn toward NGF-coated beads more frequently than toward cyto-C beads (Fig. 3, Table 1). Nerve fiber elongation and growth cone motility were not affected by the antibody. Persistent filopodial contacts, the first phase of the turning response, were established in $92 \%$ of interactions that did not result in growth cone turns, and in $30 \%$ of these cases, the growth cones reoriented toward the bead. However, the engorgement of filopodial contacts with NGFcoated beads and the migration of the growth cone underneath the bead did not occur. Hence, CTA did not prevent the formation of persistent contacts with NGF-coated beads and did not block the ability of some growth cones to orient toward the NGF-coated beads. However, CTA did prevent the local engorgement, which completes growth cone turning toward NGF-coated beads. 

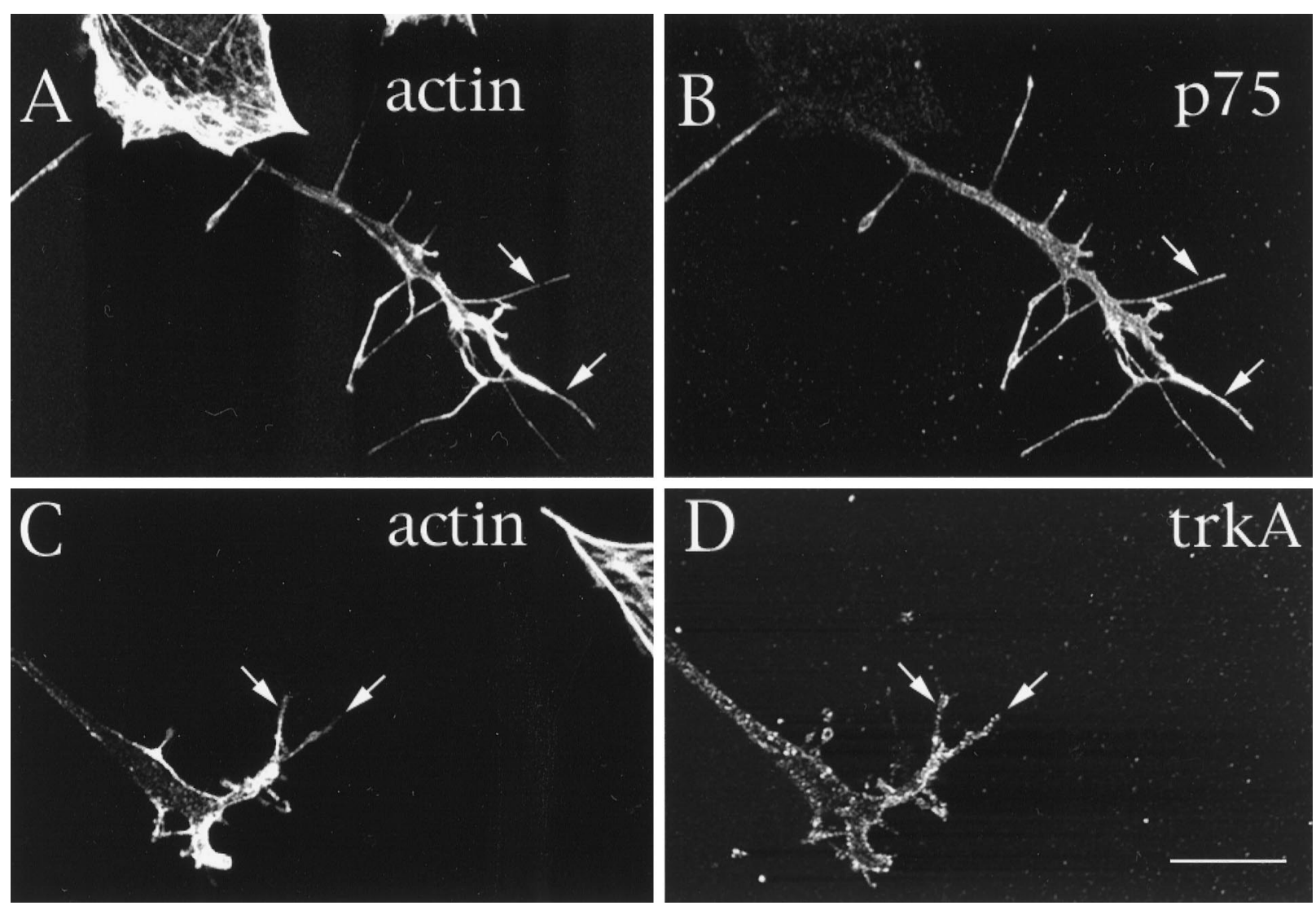

Figure 2. Immunocytochemical visualization of trkA and p75 receptors on the growth cones of DRG neurons cultured in $0.05 \mathrm{ng} / \mathrm{ml}$ NGF. $A$, Actin filaments in a growth cone and the edge of a non-neuronal cell (top left) labeled with fluorescein-phalloidin. $B$, The same cells as in $A$ labeled with 7 $\mu \mathrm{g} / \mathrm{ml}$ of the anti-p75 CHEX. The growth cone is strongly labeled, but not the non-neuronal cell. Arrows in $A$ and $B$ indicate filopodia that are labeled by anti-p75. $C$, Actin filaments in a growth cone and the edge of a non-neuronal cell (top right) labeled with fluorescein-phalloidin. $D$, The same cells as in $C$ labeled with $25 \mu \mathrm{g} / \mathrm{ml}$ of the anti-trkA CTA. The neurite and growth cone are labeled, but not the non-neuronal cell. Arrows in $C$ and $D$ indicate filopodia that are labeled by anti-trkA. Scale bar, $10 \mu \mathrm{m}$.

Blocking NGF binding to $\mathrm{p} 75$ receptors on DRG growth cones with the Chex antibody reduced the percentage of growth cones that turned toward NGF-coated beads, but to a lesser extent than did anti-trkA. Concentrations of Chex were used that were higher than those shown by Weskamp and Reichardt (1991) to fully block NGF binding to p75. In the presence of $14 \mu \mathrm{g} / \mathrm{ml} \mathrm{Chex,}$ $57 \%$ of growth cones turned after contact with NGF-coated beads (Fig. 3, Table 1), and persistent contacts occurred in $75 \%$ of interactions that did not result in growth cone turns. Fifty-nine percent of growth cones turned in the presence of $70 \mu \mathrm{g} / \mathrm{ml}$ Chex (Fig. 3, Table 1), and $71 \%$ of interactions not resulting in growth cone turns involved persistent contacts. In both concentrations of Chex, even though persistent contacts were made, filopodia often did not appear to be stabilized by the contact. During 25\% (14 $\mu \mathrm{g} / \mathrm{ml})$ and $57 \%(70 \mu \mathrm{g} / \mathrm{ml})$ of persistent contacts, the shafts of the filopodia underwent buckling and/or bending, suggesting that the filopodia were not stabilized, although they retained contact with the NGF-coated beads. Chex did not affect the life span and movements of filopodia that did not contact NGF-coated beads. Hence, Chex did not totally block the ability of growth cones to respond to NGF-coated beads, although it did decrease the frequency of growth cone turning.

We examined the effect of an antibody against the extracellular portion of another neurotrophin receptor trkB, which is a highaffinity receptor for brain-derived neurotrophic factor (BDNF) and is expressed by some DRG neurons. The addition of 20

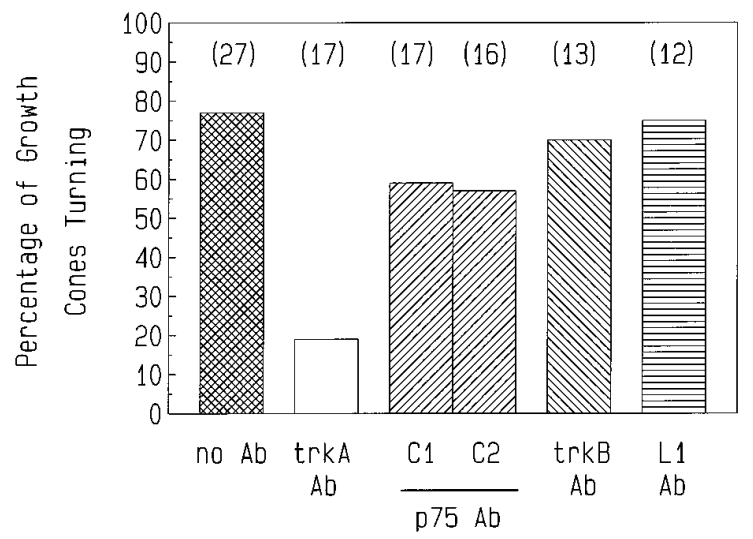

Figure 3. Inhibition of the turning response toward NGF-coated beads by the application of trkA and $\mathrm{p} 75$ receptor antibodies. In the presence of the trkA antibodies (CTA, $25 \mu \mathrm{g} / \mathrm{ml}$ ), growth cones did not turn toward NGF-coated beads more than toward cyto-C beads. Both 14 (C1) and 70 (C2) $\mu \mathrm{g} / \mathrm{ml}$ antibodies against $\mathrm{p} 75$ (Chex) diminished, but did not abolish, the turning response of growth cones toward NGF-coated beads. Antibodies against trkB $(20 \mu \mathrm{g} / \mathrm{ml})$ or $\mathrm{L} 1(25 \mu \mathrm{g} / \mathrm{ml})$ did not affect the percentage of growth cones that turned toward NGF-coated beads. The percentage of growth cones that turned toward NGF-coated beads in the absence of antibodies (no $A b$ ) is provided for comparison purposes. All experiments were performed with a $0.05 \mathrm{ng} / \mathrm{ml}$ background NGF concentration. 
Table 1. Relative decrease in growth cone turning frequency toward NGF-coated beads

Treatment or NGF background concentration

\begin{tabular}{lcc}
\hline $0.05 \mathrm{ng} / \mathrm{ml} \mathrm{NGF}$ & 27 & $100 \%$ \\
$1.0 \mathrm{ng} / \mathrm{ml}$ NGF & 18 & 50 \\
$10.0 \mathrm{ng} / \mathrm{ml} \mathrm{NGF}$ & 20 & 17 \\
$100 \mathrm{ng} / \mathrm{ml} \mathrm{NGF}$ & 15 & 0 \\
$25 \mu \mathrm{g} / \mathrm{ml}$ anti-trkA & 17 & 0 \\
$14 \mu \mathrm{g} / \mathrm{ml}$ anti-p75 antibodies & 17 & 65 \\
$70 \mu \mathrm{g} / \mathrm{ml}$ anti-p75 antibodies & 16 & 62 \\
$20 \mu \mathrm{g} / \mathrm{ml}$ anti-trkB & 13 & 85 \\
$25 \mu \mathrm{g} / \mathrm{ml}$ anti-L1 & 12 & 96 \\
$10.0 \mathrm{ng} / \mathrm{ml}$ BDNF & 10 & 88 \\
$100 \mathrm{ng} / \mathrm{ml}$ BDNF & 16 & 50 \\
$100 \mathrm{nM} \mathrm{K} 252 \mathrm{a}$ & 19 & 0 \\
$100 \mathrm{nM} \mathrm{KT5926}$ & 8 & 92 \\
$500 \mathrm{nM} \mathrm{KT5926}$ & 15 & 55 \\
$2.5 \mu \mathrm{m} / \mathrm{ml}$ DMSO & 8 & 92
\end{tabular}

Basal levels of turning toward protein-coated beads were $20 \%$ (i.e., cyto-C beads in both 0.05 and $1.00 \mathrm{ng} / \mathrm{ml} \mathrm{NGF);77 \%} \mathrm{of} \mathrm{growth} \mathrm{cones} \mathrm{turned} \mathrm{toward} \mathrm{NGF-coated}$ beads in the presence of $0.05 \mathrm{ng} / \mathrm{ml}$ NGF. Therefore, subtracting the basal level of turning toward beads, the specific response of growth cones to NGF-coated beads is represented by $77 \%-20 \%$, or $57 \%$. To obtain the changes in growth cones turning toward beads relative to basal levels, we used the following, formula: relative percentage turning $(\mathrm{RPT})=(\%$ turning $-20 \%) / 57 \%$. RPT $=0 \%$ if growth cones did not turn more often than expected by basal turning levels, and $100 \%$ if the percentage of turning was equal to that of growth cones in $0.05 \mathrm{ng} / \mathrm{ml} \mathrm{NGF}$.

$\mu \mathrm{g} / \mathrm{ml}$ anti-trkB did not significantly inhibit the turning of DRG growth cones toward NGF-coated beads (Fig. 3, Table 1). This result suggests that turning toward NGF-coated beads involves trkA receptors on DRG growth cones, but not receptors for other neurotrophins.

As a control for nonspecific effects of an antibody binding to growth cone surfaces, we added to the culture medium $25 \mu \mathrm{g} / \mathrm{ml}$ of a polyclonal antibody against the extracellular portion of the cell adhesion molecule 8D9. This antibody recognizes a chick homolog of the adhesion molecule L1, and DRG growth cones and filopodia are stained strongly by this antibody (Letourneau and Shattuck, 1989). This antibody did not disrupt the turning of DRG growth cones toward NGF-coated beads (Table 1). Thus, turning toward NGF-coated beads was not affected by the binding of an antibody to an unrelated growth cone surface component.

\section{Effects of soluble NGF on growth cone turning}

To test further whether the trkA receptor has a role in growth cone turning to NGF-coated beads, we increased the background concentration of NGF, and asked whether growth cone turning was blocked when the NGF concentration in the culture medium was at or above the $K_{\mathrm{d}}$ for $\operatorname{trkA}(\sim 1 \mathrm{ng} / \mathrm{ml})$ or the $K_{\mathrm{d}}$ for the pan-neurotrophin receptor p75 $(\sim 40 \mathrm{ng} / \mathrm{ml})$. Increasing the NGF background concentration inhibited growth cone turning in a dose-dependent manner (Fig. 4, Table 1). At $1.0 \mathrm{ng} / \mathrm{ml} \mathrm{NGF,} \mathrm{the}$ percentage of growth cones that turned toward an NGF-coated bead was decreased to $50 \%$ compared with $77 \%$ in the presence of $0.05 \mathrm{ng} / \mathrm{ml} \mathrm{NGF}$, and the presence of $10.0 \mathrm{ng} / \mathrm{ml} \mathrm{NGF} \mathrm{de-}$ creased the frequency of turning to $30 \%$. Thus, $10 \mathrm{ng} / \mathrm{ml} \mathrm{NGF}$ reduced growth cone turns toward NGF-coated beads nearly to the frequency of turning toward cyto-C beads. In the presence of $10 \mathrm{ng} / \mathrm{ml} \mathrm{NGF}$, at least one persistent filopodial contact was observed in $92 \%$ of interactions that did not result in turning, indicating that $10 \mathrm{ng} / \mathrm{ml} \mathrm{NGF}$ does not prevent stable contacts with the NGF-coated bead, but the response did not proceed to filopodial darkening/thickening and subsequent engorgement. NGF (100 ng/ml) (Fig. 4) reduced the frequency of growth cone turns toward NGF-coated beads to the same $20 \%$ level as turns toward cyto-C beads. The turning response was blocked by 100 $\mathrm{ng} / \mathrm{ml} \mathrm{NGF}$ at the filopodial darkening/thickening phase, whereas persistent contacts with NGF-coated beads were observed in $92 \%$ of the interactions that did not result in growth cone turning. Hence, growth cone turning toward NGF-coated beads was reduced nearly to the frequency of turning toward cyto- $\mathrm{C}$ beads in the presence of $10 \mathrm{ng} / \mathrm{ml} \mathrm{NGF}$, which is below the $K_{\mathrm{d}}$ for p75 (40 $\mathrm{ng} / \mathrm{ml})$ and above the $K_{\mathrm{d}}$ of the trkA receptor $(\sim 1 \mathrm{ng} / \mathrm{ml})$. Our finding that the presence of $100 \mathrm{ng} / \mathrm{ml} \mathrm{NGF}$ further reduced turning toward NGF-coated beads to the same frequency that we observed with cyto- $\mathrm{C}$ beads supports the idea from our antibody experiments that both the trkA and the p75 NGF receptors are involved in the turning response (Table 1).

\section{Effects of bath-applied BDNF on the turning response}

To further probe the role of the p75 pan-neurotrophin receptor in growth cone turning toward NGF-coated beads, we asked whether saturation of the $\mathrm{p} 75$ receptor with a different neurotrophin would impair growth cone turning. Because BDNF binds p75 but not trkA, we co-administered NGF-coated beads and 100 $\mathrm{ng} / \mathrm{ml} \mathrm{BDNF}$ (the $K_{\mathrm{d}}$ for BDNF binding to $\mathrm{p} 75$ is $\sim 40 \mathrm{ng} / \mathrm{ml}$ ) to DRG neurons that were cultured overnight in $0.05 \mathrm{ng} / \mathrm{ml} \mathrm{NGF}$. This treatment reduced the percentage of growth cones that turned toward NGF-coated beads to $50 \%$ (Fig. 4, Table 1). Persistent filopodial contacts were made during $77 \%$ of interactions that did not result in growth cone turning. BDNF (10 $\mathrm{ng} / \mathrm{ml})$, unlike NGF (10 $\mathrm{ng} / \mathrm{ml})$, did not affect growth cone turning toward NGF-coated beads (Fig. 4, Table 1).

To test whether the interaction of the NGF-coated beads with p75 receptors could be sufficient for a turning response toward NGF-coated beads, we cultured DRG neurons overnight in the presence of $0.05-30 \mathrm{ng} / \mathrm{ml} \mathrm{BDNF}$ and no NGF, and then presented growth cones with NGF-coated beads. The rationale for this experiment is to select for neurons with p75 and trkB, the receptor for $\mathrm{BDNF}$, whereas neurons expressing trkA alone would not survive in the absence of NGF. We presented NGFcoated beads to BDNF-raised growth cones in the presence of $0.05,10$, or $30 \mathrm{ng} / \mathrm{ml} \mathrm{BDNF}$, but in no case did the growth cones selectively turn toward NGF-coated beads (Table 2). Hence, growth cones of DRG neurons raised in BDNF did not respond specifically to NGF-coated beads beyond forming stable filopodial contacts with beads.

\section{K252a blocks growth cone turning toward NGF-coated beads}

K252a and KT5926 are related protein kinase inhibitors that affect a similar set of kinases (Hashimoto et al., 1991). K252a, but not KT5926, also inhibits the autophosphorylation and subsequent signal transduction of trkA in response to NGF (Koizumi et al., 1988; Berg et al., 1992; Muroya et al., 1992; Nye et al., 1992; Tapley et al., 1992; Teng and Greene, 1994). The addition of 100 nм K252a, a concentration that fully blocked trkA autophosphorylation in PC12 cells (Berg et al., 1992; Tapley et al., 1992), inhibited growth cone turning toward NGF-coated beads (Fig. 5) without inhibiting growth cone motility during a $2 \mathrm{hr}$ period after its introduction. However, in the presence of $100 \mathrm{~nm} \mathrm{~K} 252 \mathrm{a}$ persistent filopodial contacts were established in $89 \%$ of the interactions that did not result in turning, and during $33 \%$ of 
A

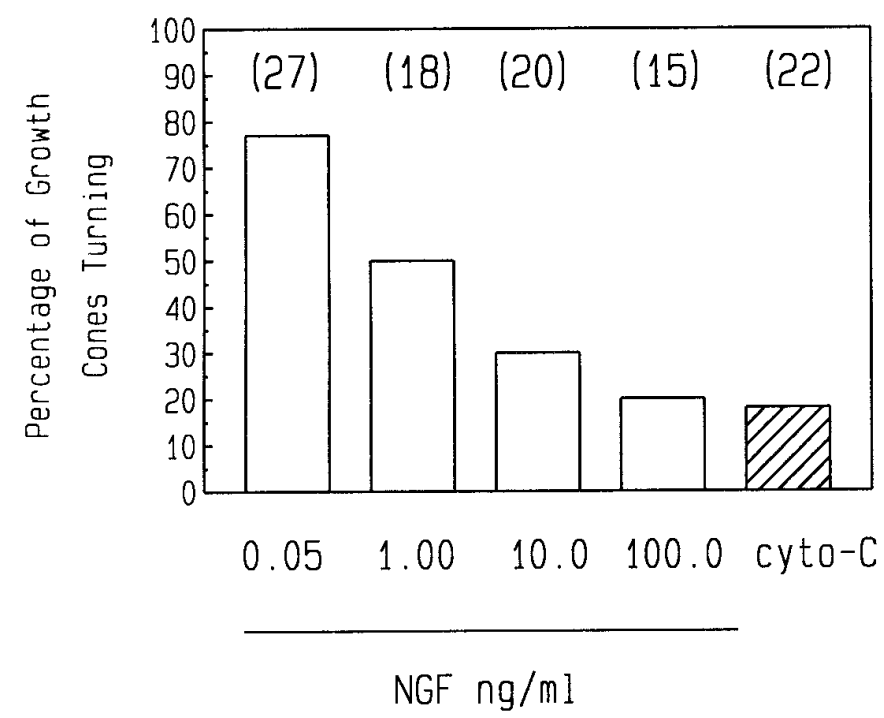

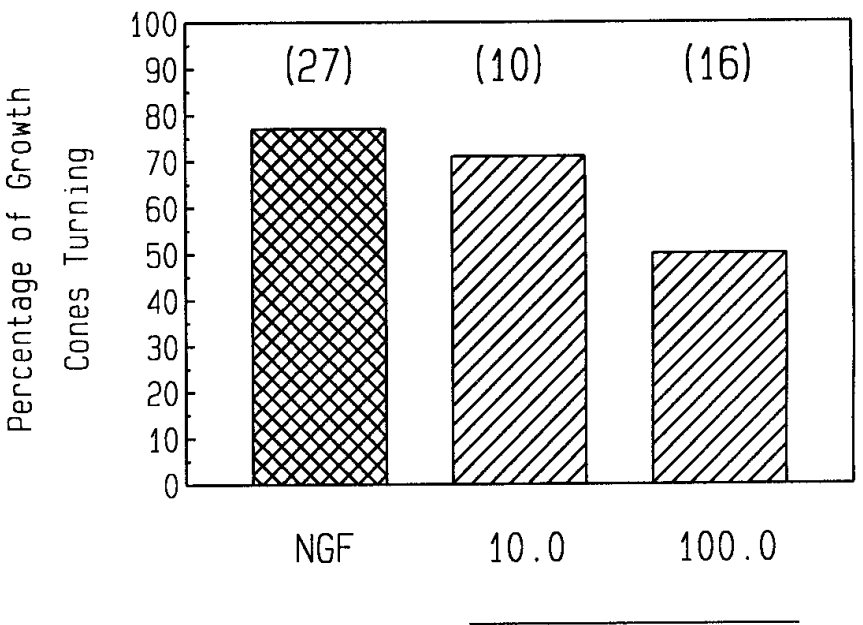

BDNF ng/ml

Figure 4. Soluble NGF and BDNF affect growth cone turning toward NGF-coated beads. $A$, Increasing the background NGF concentration decreased the percentage of growth cones that turned toward NGF-coated beads. The percentage of growth cones that turned toward cyto-C-coated beads in 0.05 $\mathrm{ng} / \mathrm{ml} \mathrm{NGF}$ is presented for comparison purposes and establishes the basal level of turning toward protein-coated beads. $B$, Adding $100 \mathrm{ng} / \mathrm{ml} \mathrm{BDNF}$ to the culture medium $(0.05 \mathrm{ng} / \mathrm{ml} \mathrm{NGF}$ background) resulted in a decrease in the percentage of growth cones that turned toward NGF-coated beads, whereas $10 \mathrm{ng} / \mathrm{ml} \mathrm{BDNF}$ did not have a similar effect. The percentage of growth cones that turned toward NGF-coated beads in $0.05 \mathrm{ng} / \mathrm{ml}$ NGF is presented for comparison.

\begin{tabular}{llll}
\hline \multicolumn{3}{l}{ Table 2. Responses of BDNF-raised DRG neurons to NGF-coated beads } \\
$\begin{array}{l}\text { Concentration of } \\
\text { BDNF }(\mathrm{ng} / \mathrm{ml})\end{array}$ & $(n)$ & $\begin{array}{l}\text { \% Growth cone } \\
\text { turning }\end{array}$ & $\begin{array}{l}\text { \% Persistent } \\
\text { contacts }\end{array}$ \\
\hline 0.05 & 12 & 17 & 90 \\
10.00 & 10 & 10 & 90 \\
30.00 & 17 & 24 & 75
\end{tabular}

Concentration of BDNF refers to the concentration the neurons were raised in and that which was also present when NGF-coated beads were introduced to the cultures. Percent persistent contacts refers to the percentage of growth cones that did not turn after contact with an NGF-coated bead but that formed persistent contacts with the beads (see text for the definition of persistent contact).

these interactions, growth cone reorientation was observed. In the presence of $\mathrm{K} 252 \mathrm{a}$, the turning response did not proceed further than the formation of stable filopodial contacts.

Although the frequency of turning was not affected by $100 \mathrm{~nm}$ KT5926, 500 nм KT5926 did (Fig. 5) produce aborted growth cone turns toward NGF-coated beads. Some growth cones underwent the initial stages of engorgement of the contact, but engorgement was not completed and was eventually reversed (Fig. 1). In addition, even when turning did occur, the time interval from initial contact with the bead to when the growth cone either turned toward the bead or continued migrating without turning was lengthened to $22.30 \pm 4.14$ min (mean $\pm \mathrm{SEM} ; p<0.02$ compared with $8.71+1.17 \mathrm{~min}$ in the absence of any drug, Welch's $t$ test). Exposure (1-2 hr) to 500 nм KT5926 did not decrease the elongation rate of DRG nerve fibers (Welch's $t$ test, $p>0.05 ; n=$ 56 and 67 for nerve fibers in the presence of KT5926 and 1:4000 DMSO, respectively), although $2 \mu \mathrm{M}$ concentrations of KT5926 halt nerve fiber growth (Teng and Greene, 1994). Thus, in the presence of $100 \mathrm{~nm} \mathrm{K252a}$, growth cone responses to NGF-coated beads did not proceed further than the formation of the initial

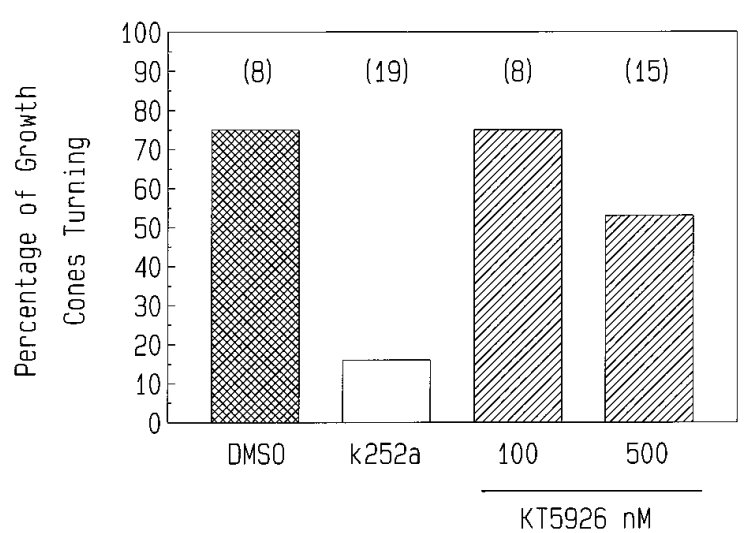

Figure 5. K252a, but not its analog KT5926, inhibited the turning response toward NGF-coated beads. In the presence of $100 \mathrm{~nm} \mathrm{K252a,} \mathrm{the}$ percentage of growth cones that turned was not greater than that observed with cyto-C beads (see previous figures). Whereas $100 \mathrm{~nm}$ KT5926 had no effect on growth cone turning toward NGF-coated beads, $500 \mathrm{~nm}$ caused a decrease in the percentage of growth cones that turned. The vehicle for K252a and KT5926, DMSO at a concentration of $2.5 \mu \mathrm{g} / \mathrm{ml}$, did not affect growth cone turning. All experiments were performed with a background NGF concentration of $0.05 \mathrm{ng} / \mathrm{ml}$.

contact, whereas 500 nм KT5926 caused a partial block of growth cone turning at a late stage in the process. The vehicle for $\mathrm{K} 252 \mathrm{a}$ and KT5926 (DMSO) did not affect the turning response (Fig. 5).

\section{DISCUSSION}

We have developed a system for studying the guidance of growth cones by neurotrophins. On contacting an NGF-coated bead, NGF-responsive DRG growth cones turned and migrated underneath the bead. The turning response of growth cones involved the formation and stabilization of a filopodial contact with an 
NGF-coated bead, followed by engorgement of the contact and elongation of the nerve fiber toward the bead. Our data indicate that both low- and high-affinity NGF receptors are involved, albeit to different extents, in mediating this response. These results provide the first evidence of a role for a trk receptor in locally regulating nerve growth cone behavior.

\section{The role of the high-affinity NGF receptor (trkA)}

A necessary role for the trkA receptor in mediating turning toward NGF-coated beads is supported by three independent lines of evidence. First, antibodies against the extracellular domain of trkA blocked the turning response. Second, raising the extracellular NGF concentration to saturate trkA blocked the response. Third, growth cone turning was prevented by a concentration of K252a that inhibits trkA autophosphorylation and signaling. In all these instances, the initial filopodial contacts with beads were formed and maintained, but the growth cones did not turn toward NGF-coated beads more than toward control beads.

The inhibition of turning by K252a is attributable to its block of NGF activation of trkA (Berg et al., 1991; Tapley et al., 1992). Even though trkA receptors in the growth cone membrane bound NGF on the bead, K252a prevented trkA autophosphorylation and the subsequent signaling cascade. The response proceeded no further than formation of persistent contacts of filopodia with NGF-coated beads, suggesting that trkA-mediated signaling is required for the cytoskeletal changes that produce the filopodial thickening and subsequent engorgement.

What is the mechanism by which the soluble NGF and the trkA divalent antibody blocked the turning response? Two, not mutually exclusive, alternatives are worth considering. Possibly, these molecules directly competed or interfered with the binding of filopodial trkA receptors to the bead-bound NGF, thereby interfering with local activation of trkA. In addition, both treatments might activate trkA over the entire growth cone and neuron. Indeed, $10 \mathrm{ng} / \mathrm{ml}$ NGF maximally stimulates trkA autophosphorylation in PC12 cells (Kaplan et al., 1991). If local filopodial thickening and engorgement require local activation of trkA, both treatments would prevent this by activating trkA everywhere on the growth cone, rendering the growth cone unable to detect the bead-bound NGF.

\section{The role of the low-affinity NGF receptor (p75)}

Our data indicate that the p75 receptor is also involved in the turning response. This conclusion is supported by our findings that the incidence of persistent filopodial contacts with NGFcoated beads and the percent of growth cone turns toward NGFcoated beads were reduced by the Chex antibody, which blocks NGF binding to p75 (Weskamp and Reichardt, 1991), and by saturation of the p75 receptor with $100 \mathrm{ng} / \mathrm{ml}$ BDNF, which competes with bead-bound NGF for binding to p75 receptors on filopodia. It should be noted that growth cones of DRG neurons cultured overnight in $0.05-10 \mathrm{ng} / \mathrm{ml} \mathrm{BDNF}$, which would express p75 but perhaps not functional trkA receptors, made persistent filopodial contacts with NGF-coated beads but did not turn more often toward them than toward cyto- $\mathrm{C}$ beads. These results are consistent with a proposal that the p75 receptor has a role in establishing filopodial contacts with NGF-coated beads. Based on published numbers of about 2000 trkA receptors and 23,00045,000 p75 receptors on a DRG neuron (Meakin and Shooter, 1992), it may be that the tips of many filopodia express few or no trkA receptors. It is much more likely that the p75 receptors would mediate the first binding to NGF on a bead. These initial bonds may hold and expand the filopodial contact with a bead until the less numerous trkA receptors also interact with the bead-bound NGF. The p75 receptor may potentiate the interaction of trkA with the bead-bound NGF, as it does in the case of soluble NGF (Barker and Shooter, 1994; Lee et al., 1994b; Mahadeo et al., 1994). The partial inhibition of turning by adding Chex or high BDNF to block binding of bead-bound NGF to filopodial p75 receptors indicates that p75 and its localized signaling is unnecessary for growth cone turning, and the results with BDNF-raised neurons suggest that expression of p75 is insufficient for turning toward NGF-coated beads. The issue of sufficiency would be clarified by genetic manipulations of cellular expression of individual receptor types.

\section{A working model for the mechanism of the turning response}

Collectively, our data suggest a model for the events of growth cone turning toward a source of NGF [Fig. $6 A$ (growth cone filopodia sample the environment), $B$ (a filopodium contacts a bead), and $C$ (stabilization of the contact)]. At this point, trkAmediated signaling may begin (Fig. 6, shaded regions). NGF binding to p75 and trkA may result in stabilization of the filopodium, preventing it from buckling. This stabilization may involve local accumulation of actin filaments in the filopodium, as was observed during growth cone turning in the grasshopper limb bud (Bentley and O'Connor, 1994) or in response to contacting the surface of a nerve fiber (Lin et al., 1994). Because calcium regulates actin filaments in growth cones (Lankford and Letourneau, 1989, 1991), these alterations in the cytoskeleton may involve a trkA-mediated rise in intracellular calcium levels (De Bernardi et al., 1996). Fig. $6 D$ shows engorgement of the contact. The effects of K252a indicate that signal transduction through the trkA receptor is required for the engorgement of a stabilized contact with a bead. We suggest that an intracellular asymmetry in trkA activation occurs with the highest level of activation at the site of contact with the NGF-coated bead. The subsequent cascade of protein phosphorylation may initiate the recruitment of microtubules and organelles in the direction of contact, thereby causing a localized engorgement of the growth cone. Our data suggest that KT5926 blocks a kinase(s) that is downstream of trkA activation and is required to sustain cytoplasmic engorgement toward the site of contact. Indeed, concentrations of KT5926 greater than those used in this study inhibit NGFstimulated nerve fiber outgrowth and phosphorylation of a microtubule-associated protein (Teng and Greene, 1994). Fig $6 E$ shows consolidation of the growth cone proximal to the contacts, and $F$ shows emergence of the growth cone underneath the bead and migration in a new direction. These last two steps may not be selectively affected by the local NGF signal, but they are part of the normal events of nerve fiber elongation (Aletta and Greene, 1986; Goldberg and Burmeister, 1986).

\section{Relevance of the present findings to in vivo neurodevelopment}

These results support a role for NGF in axonal morphogenesis and local nerve-target relationships. In vitro experiments (Letourneau, 1978; Gundersen and Barrett, 1979) showed that NGF can be a chemoattractant, although in vivo studies suggested that NGF is not a long-range chemoattractant in the peripheral nervous system (Lumsden and Davies, 1983; Davies et al., 1987). However, recent studies indicate that neurons express NGF receptors before their axons reach their targets (Mu et al., 1993; Wyatt and 
A
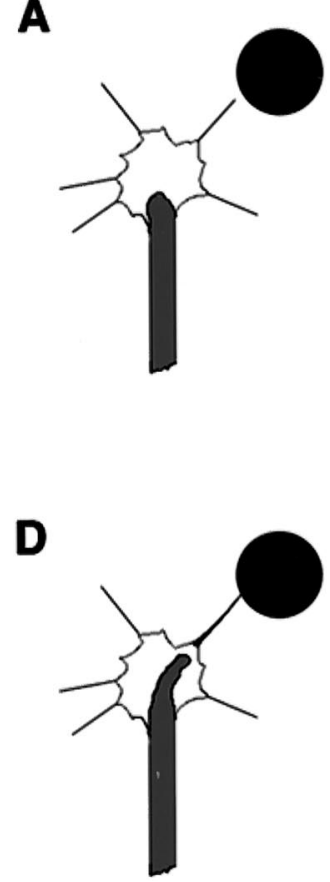

B

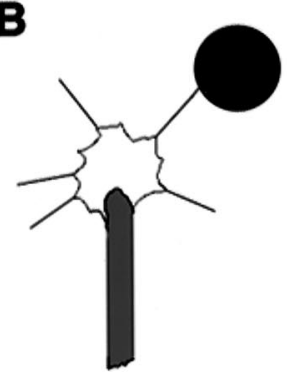

$\mathbf{E}$

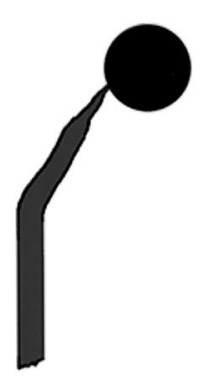

C

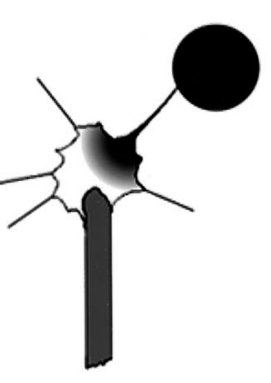

$\mathbf{F}$

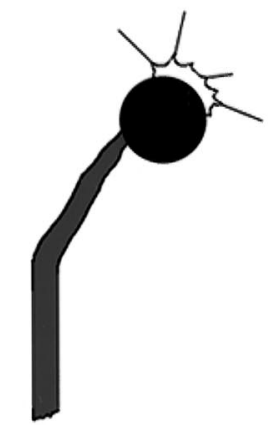

Figure 6. Working model for the mechanism of growth cone turning toward NGFcoated beads. See the Discussion for details.
Davies, 1993; Hallbook et al., 1995), and NGF is expressed early by target tissues and by cells along developing axonal pathways (Ebendal and Persson, 1988; Elkabes et al., 1994; Yao et al., 1994; Hallbook et al., 1995). Thus, NGF-receptor interactions may provide local guidance cues at intermediate points or when axons reach their targets. This would be an addition to the increasing number of tyrosine kinase receptors that are involved in axonal pathfinding (Goodman, 1996; McFarlane et al., 1996). Interestingly, hepatocyte growth factor, which activates the receptor tyrosine kinase c-Met, has recently been shown to be a target tissue-derived chemotropic guidance cue (Ebens et al., 1996).

Genetic manipulations of expression of NGF and the p75 receptors also suggest roles for $\mathrm{NGF}$ in regulating nerve fiber morphogenesis in target tissues. Hoyle et al. (1993) produced transgenic mice in which sympathetic neurons expressed NGF, creating a high NGF environment around the developing neuron. Sympathetic ganglia were greatly enlarged in these animals, and their axons exhibited normal pathfinding to their targets. Yet the growth cones of the NGF-expressing sympathetic axons failed to normally invade and arborize in their targets. However, this abnormal phenotype was reversed by additional manipulation to overexpress NGF in the target (Hoyle et al., 1993). These in vivo experiments resemble our in vitro experiments in which elevation of the background NGF concentration prevented growth cone responses to NGF-coated beads. Transgenic NGF overexpression in heart also lead to cardiac hyperinnervation (Hassankhani et al., 1995). Regarding the p75 NGF receptor, anatomical studies of p75 null mutant mice report decreased innervation of several targets by sensory and sympathetic axons and decreased arborizations by some NGF-responsive axons within their targets (Lee et al., 1994a).

Thus, in view of these in vivo data, our results suggest a mechanism for local regulation of axonal morphogenesis by NGF. NGF-responsive growth cones may encounter high local concentrations of NGF that is either diffusible or bound to extracellular components. In such a situation, our data imply that the local activation of trkA on the growth cones would induce cytoskeletal rearrangements, resulting in directed migration and branching of the developing axons.

\section{REFERENCES}

Aletta JM, Greene LA (1988) Growth cone configuration and advance: a time-lapse study using video-enhances differential interference contrast microscopy. J Neurosci 8:1425-1435.

Barbacid M (1995) Neurotrophic factors and their receptors. Curr Opin Cell Biol 7:148-155.

Barker PA, Shooter EM (1994) Disruption of NGF binding to the low affinity neurotrophin receptor $\mathrm{p} 75^{\mathrm{LNTR}}$ reduces NGF binding to trkA on PC12 cells. Neuron 13:203-215.

Bentley D, O'Connor T (1994) Cytoskeletal events in growth cone steering. Curr Opin Neurobiol 4:43-48.

Berg MM, Sternberg DW, Parada LF, Chao MV (1992) K-252a inhibits nerve growth factor-induced trk proto-oncogene tyrosine phosphorylation and kinase activity. J Biol Chem 267:13-16.

Berninger B, Poo M-M (1996) Fast actions of neurotrophic factors. Curr Opin Neurobiol 6:324-330.

Campenot RB (1994) NGF and the local control of nerve terminal growth. J Neurobiol 25:599-611.

Challacombe JF, Snow D, Letourneau PC (1996) Role of the cytoskeleton in growth cone motility and axonal elongation. Semin Neurosci 8:67-80.

Davies AM, Bandtlow C, Heumann R, Korsching S, Rohrer H, Thoenen $H$ (1987) Timing and site of nerve growth factor synthesis in developing skin in relation to innervation and expression of the receptor. Nature 326:353-358.

De Bernardi MA, Rabin SJ, Colangelo AM, Brooker G (1996) trkA mediates the nerve growth factor-induced intracellular calcium accumulation. J Biol Chem 271:6092-6098.

Dobrowsky RT, Werner MH, Castellino AM, Chao MV, Hannun YA (1994) Activation of the sphingomyelin cycle through the low-affinity neurotrophin receptor. Science 265:1596-1599.

Ebendal T, Persson H (1988) Detection of nerve growth factor mRNA in the developing chicken embryo. Development 102:101-106.

Ebens A, Brose K, Leonardo ED, Hanson Jr MG, Bladt F, Birchmeier C, Barres BA, Tessier-Lavighe M (1996) Hepatocyte growth factor/scatter factor is an axonal chemoattractant and a neurotrophic factor for spinal motor neurons. Neuron 17:1157-1172.

Elkabes S, Dreyfus CF, Schaar DG, Black IB (1994) Embryonic sensory development: local expression of neurotrophin-3 and target expression of nerve growth factor. J Comp Neurol 341:204-213. 
Fan J, Raper JA (1995) Localized collapsing cues can steer growth cones without inducing their full collapse. Neuron 14:263-274.

Farinas I, Reichardt LF (1996) Neurotrophic factors and their receptors-Implications of genetic studies. Semin Neurosci 8:133-143.

Goldberg DJ, Burmeister DW (1986) Stages in axon formation: observations of growth cones of Aplysia axons in culture using videoenhanced contrast-differential interference contrast microscopy. J Cell Biol 104:1921-1931.

Gomez TM, Letourneau PC (1994) Filopodia initiate choices made by sensory neuron growth cones at laminin/fibronectin borders in vitro. J Neurosci 14:5959-5972.

Goodman CS (1996) Mechanisms and molecules that control growth cone guidance. Annu Rev Neurosci 19:341-377.

Greene LA, Kaplan DR (1995) Early events in neurotrophin signaling via trk and p75 receptors. Curr Opin Neurobiol 5:579-587.

Gundersen RW (1985) Sensory neurite growth cone guidance by substrate adsorbed nerve growth factor. J Neurosci Res 13:199-211.

Gundersen RW, Barrett JN (1979) Neuronal chemotaxis: chick dorsalroot axons turn toward high concentrations of nerve growth factor. Science 206:1079-1080.

Hallbook F, Backstrom A, Kullander K, Kylberg A, Williams R, Ebendal $\mathrm{T}$ (1995) Neurotrophins and their receptors in chicken neuronal development. Int J Dev Biol 39:855-868.

Hashimoto Y, Nakayama T, Termamoto T, Kato H, Watanabe T, Kinoshita M, Tsukamoto K, Tokunaga K, Kurokawa K, Nakanishi S, Matsuda Y, Nonomura Y (1991) Potent and preferential inhibition of $\mathrm{Ca}^{2++} /$ calmodulin-dependent protein kinase II by K252a and its derivative, KT5926. Biochem Biophys Commun 181:423-429.

Hassankhani A, Steinhelper ME, Soonpaa MH, Katz EB, Taylor DA, Andrade-Rozental A, Factor SM, Steinberg JJ, Field LJ, Federoff HJ (1995) Overexpression of NGF within the heart of transgenic mice causes hyperinnervation, cardiac enlargement, and hyperplasia of ectopic cells. Dev Biol 169:309-321.

Henderson CE (1996) Role of neurotrophic factors in neuronal development. Curr Opin Neurobiol 6:64-70.

Heumann R (1994) Neurotrophin signaling. Curr Opin Neurobiol 4:668-679.

Hoyle GW, Mercer EH, Palmiter RD, Brinster RL (1993) Expression of NGF in sympathetic neurons leads to excessive axon outgrowth from ganglia but decreased terminal innervation within tissues. Neuron 10:1019-1034.

Huber LJ, Chao MV (1995) A potential interaction of p75 and trkA NGF receptors demonstrated by affinity cross-linking and immunoprecipitation. J Neurosci Res 40:557-563.

Kaplan DR, Stephens RM (1994) Neurotrophin signal transduction by the trk receptor. J Neurobiol 25:1404-1417.

Kaplan DR, Martin-Zanca D, Parada LF (1991) Tyrosine phosphorylation and tyrosine kinase activity of the trk-oncogene product induced by NGF. Nature 350:158-160.

Kashiba H, Noguchi K, Ueda Y, Senba E (1995) Coexpression of trk family members and low-affinity neurotrophin receptors in rat dorsal root ganglion neurons. Brain Res Mol Brain Res 30:158-164.

Kennedy TE, Tessier-LaVigne M (1995) Guidance and induction of branch formation in developing axons by target-derived diffusible factors. Curr Opin Neurobiol 5:83-90.

Koizumi S, Contreras ML, Matsuda Y, Hama T, Lazarovici P, Guroff G (1988) K-252a: A specific inhibitor of the action of nerve growth factor on PC12 cells. J Neurosci 8:715-721.

Kuhn TB, Schmidt MF, Kater SB (1995) Laminin and fibronectin guideposts signal sustained but opposite effects to passing growth cones. Neuron 14:275-285.

Lankford KL, Letourneau PC (1989) Evidence that calcium may control neurite outgrowth by regulating the stability of actin filaments. J Cell Biol 109:1229-1243.

Lankford KL, Letourneau PC (1991) Roles of actin filaments and three second-messenger systems in short-term regulation of chick dorsal root ganglion neurite outgrowth. Cell Motil Cytoskeleton 20:7-29.

Lee K, Bachman K, Landis S, Jaenisch R (1994a) Dependence on p75 for innervation of some sympathetic targets. Science 263:1447-1449.

Lee K, Davies AM, Jaenisch R (1994b) p75-deficient embryonic dorsal root sensory and neonatal sympathetic neurons display a decreased sensitivity to NGF. Development 120:1027-1033.

Lefcort F, Clary DO, Seghal R, Reichardt LF (1994) Antibodies to the extracellular domain of avian TrkC significantly reduce the size of brachial DRG in vivo. Soc Neurosci Abstr 20:238.

Letourneau PC (1978) Chemotactic response of nerve fiber elongation to nerve growth factor. Dev Biol 66:183-196.

Letourneau PC, Shattuck TA (1989) Distribution and possible interactions of actin-associated proteins and cell adhesion molecules of nerve growth cones. Development 105:505-519.

Letourneau PC, Kater S, Macagno E (1991) The nerve growth cone. New York: Raven.

Lin C, Thompson CA, Forscher P (1994) Cytoskeletal reorganization underlying growth cone motility. Curr Opin Neurobiol 4:640-647.

Luduena MA (1973) The growth of spinal ganglion neurons in serum free medium. Dev Biol 33:470-476.

Lumsden AGS, Davies AM (1983) Earliest sensory nerve fibers are guided to peripheral targets by attractants other than nerve growth factor. Nature 306:786-788.

Mahadeo D, Kaplan L, Chao MV, Hempstead BL (1994) High affinity nerve growth factor binding displays a faster rate of association than p140trk binding. Implications for multi-subunit polypeptide receptors. J Biol Chem 269:6884-6891.

McFarlane S, Cornel E, Amaya E, Holt CE (1996) Inhibition of FGF receptor activity in retinal ganglion call axons causes errors in target recognition. Neuron 17:245-254.

Meakin SO, Shooter EM (1992) The nerve growth factor family of receptors. Trends Neurosci 15:323-331.

Mearow KM, Kril T, Diamond J (1993) Increased NGF mRNA expression in denervated rat skin. NeuroReport 4:351-354.

Menesini-Chen MG, Chen JS, Levi-Montalcini R (1978) Sympathetic nerve fiber growth in the central nervous system of neonatal rodents upon intracerebral NGF injection. Arch Ital Biol 116:53-84.

Mitchison T, Kirschner M (1988) Cytoskeletal dynamics and nerve growth. Neuron 1:761-772.

Mu X, Silos-Santiago I, Carroll SL, Snider WD (1993) Neurotrophin receptor genes are expressed in distinct patterns in developing dorsal root ganglia. J Neurosci 13:4029-4041.

Muroya K, Hashimoto Y, Hattori S, Nakamura S (1992) Specific inhibition of NGF receptor tyrosine kinase activity by K-252a. Biochim Biophys Acta 1135:353-356.

Nye SH, Squinto SP, Glass DJ, Stitt TN, Hantsopoulos P, Macchi MJ, Lindsay NS, Ip NY, Yancopoulos GD (1992) K-252a and staurosporine selectively block autophosphorylation of neurotrophin receptors and neurotrophin-mediated responses. Mol Biol Cell 3:677-686.

Oakley RA, Tosney KW (1993) Contact-mediated mechanisms of motor axon segmentation. J Neurosci 13:3773-3792.

Oakley RA, Lefcort FB, Clary DO, Reichardt LF, Prevette D, Oppenheim RW, Frank E (1997) Neurotrophin-3 promotes the differentiation of muscle spindle afferents in the absence of peripheral targets. J Neurosci 17:4262-4274.

Tanaka E, Sabry E (1995) Making the connection: cytoskeletal rearrangements during growth cone guidance. Cell 83:171-176.

Tapley P, Lamballe F, Barbacid M (1992) K252a is a selective inhibitor of the tyrosine protein kinase activity of the trk family of oncogenes and neurotrophin receptors. Oncogene 7:371-381.

Teng KK, Greene LA (1994) KT5926 selectively inhibits growth factordependent neurite elongation. J Neurosci 14:2624-2635.

Weskamp G, Reichardt LF (1991) Evidence that biological activity of NGF is mediated through a novel class of high affinity receptors. Neuron 6:649-663.

Wolf DE, McKinnon CA, Daou MC, Stephens RM, Kaplan DR, Ross AH (1995) Interaction with trkA immobilizes gp75 in the high affinity nerve growth factor receptor complex. J Biol Chem 270:2133-2138.

Wyatt S, Davies AM (1993) Regulation of expression of mRNAs encoding the nerve growth factor receptors $\mathrm{p} 75$ and trkA in developing sensory neurons. Development 119:635-648.

Yao L, Zhang D, Bernd P (1994) The onset of neurotrophin and trk mRNA expression in early embryonic tissues of the quail. Dev Biol 165:727-730.

Yeo TT, Longo FM, Bredesen DE, Butcher LL (1996) Dependence of basal forebrain cholinergic innervation of the limbic system on the $\mathrm{p} 75$ $\mathrm{NgF}$ receptor. Soc Neurosci Abstr 22:1008.

Zhang L, Schmidt RE, Yan W, Snider WD (1994) NGF and NT-3 have differing effects on the growth of dorsal root axons in developing mammalian spinal cord. J Neurosci 14:5187-5201. 